International Journal of Social Sciences and Humanities
Available online at http://sciencescholar.us/journal/index.php/ijssh
Vol. 3 No. 2, August 2019, pages: 62 70
e-ISSN: 2550-7001, p-ISSN: 2550-701X
https://doi.org/10.29332/ijssh.v3n2.293

\title{
Self-disclosure Effect on Cultural Context of Papuan Teenagers
}

Maryam B. Gainau ${ }^{a}$

Article history: Received 27 December 2018, Accepted: 30 April 2019, Published: 03 July 2019

\section{Correspondence Author ${ }^{\mathrm{a}}$}

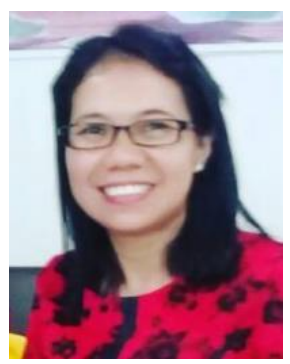

Keywords

culture;

Papuan;

quantitative;

self-disclosure;

teenagers;

\begin{abstract}
Self-disclosure is revealed through various phenomena such as information on behavior, attitudes, feelings, desires, motivations, and ideas. Related to the statement, this study aims to analyze the relationship between self-disclosure to the culture of Papuan teenagers. The sample of the current study was teenager students of Middle School in Sentani, Papua- Indonesia. In the study, a random technique was applied in order to gain 183 students as the total sample. They were $20 \%$ of the 919 teenager students. The quantitative approach was applied to examine the instruments of validity and reliability, factor analysis, t-test, and correlation coefficient. The results have shown that from 78 statement items of self-disclosure, 64 statement items were declared valid while 14 others were not valid. For 85 items about culture, there were 68 valid statement items while 17 were invalid. The self-disclosure analysis of reliability was 0.823 while the culture analysis was 0.810 . Furthermore, factor analysis has shown that from 64 items of self-disclosure statements, 60 items were stated to be fulfilled while 4 other items were not fulfilled. The results of the correlation coefficient were obtained at $86.5 \%$. It is concluded that selfdisclosure has a strong and significant effect on the culture of Papuan teenagers.
\end{abstract}

e-ISSN: 2550-7001, p-ISSN: 2550-701X ๑ Copyright 2019. The Author. SS Journals Published by Universidad Técnica de Manabí. This is an open-access article under the CC BY-SA 4.0 license (https://creativecommons.org/licenses/by-sa/4.0/) All rights reserved.

\section{Contents}

Abstract

1. Introduction.

2. Materials and Methods.

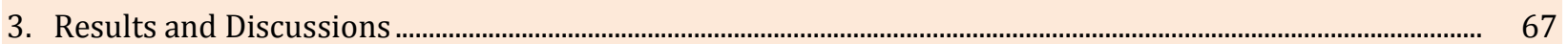

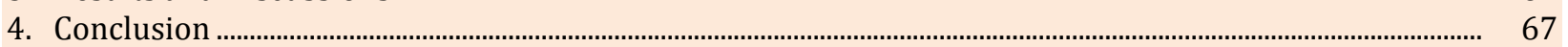

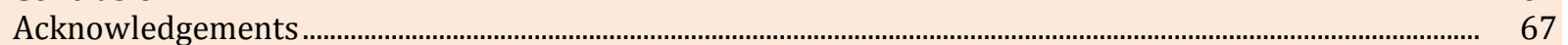

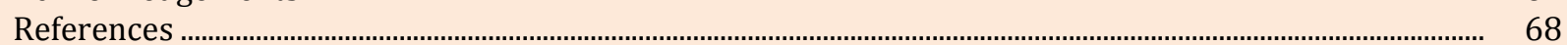

a Sekolah Tinggi Agama Kristen Negeri (STAKN) Papua, Indonesia 


\section{Introduction}

Humans are social beings who always need other people. As social beings, humans are always related to their environment (Corey, 2015). Establishing relationships with other individuals in the environment is an inseparable part of humans' life. For example, in a family environment, there is an interaction between family members, in a community environment, there is a relationship between individuals. Larasati (1992), suggests that about $73 \%$ of communication made by humans is a kind of interpersonal communication. Interpersonal communication helps individuals to grow and to develop in their social environment.

Harmonious relationships between individuals can be achieved if there is an adjustment from everyone. Adjustment to the social environment is one of the psychological aspects that need to be developed in the lives of individuals. It is conducted to other individuals, both in the group and outside the group. In order to be able to adjust to the social environment, individuals need social skills. Social skills support success in socializing and the conditions for achieving good social adjustment in an individual's life.

One important aspect of social skills is self-disclosure (Buhrmester, 1998). Lumsden \& Krumlauf (1996), state that self-disclosure can help one to communicate, increase self-confidence as well as building relationship among other people. In addition, self-disclosure can release feelings of guilt and anxiety (Calhoun \& Accocella, 1990). Without self-disclosure, individuals tend to get unfavorable opinions on social acceptance, and thus influence the development of their personality. A study conducted by Gainau (2009), has shown that $68.80 \%$ of students in Indonesia had superficial self-disclosure, while the rest were only $31.11 \%$ of students had deep self-disclosure.

Self-disclosure, which is shown in various topics, is concerned to other people. It is influenced by other people behavior, attitudes, feelings, desires, motivations, and ideas. The depth disclosure of a person is depended on the situation as well as on the interaction with other people. If the interaction is fun, for example, and make them feel safe and can arouse enthusiasm, then the possibility for individuals to be more open is bigger. In other words, the better the interaction, the bigger the self-disclosure can be seen. In contrary, certain people will just close themselves since they feel less trust (Devito et al., 2001; Agra et al., 2018; Ardhana \& Wijaya, 2017).

Self-disclosure is also influenced by several other factors, including disclosure from others, group size, topic, valence, relationship with recipient and gender (Devito et al., 2001; Taylor et al., 1997). Furthermore, it can be influenced by culture. Each nation with its own cultural style gives a certain extent to what individuals deserve or do not deserve (Kellam et al., 1983). From the results of the research of Kellam et al., (1983), it is found that Americans seem to be more open than Germans. However, this openness is only limited to surface matters and is very reluctant to open secrets that concern them personally. Germans were initially more difficult to express themselves even for things that were surface, but if they had put their trust in, they were not reluctant to reveal their deepest personal secrets.

There is a culture that tends to close itself. However, some others are open. For example in Indonesia, especially Javanese culture. Suseno \& Reksosusilo (1983), assume that silent or closed people are considered as good people. For them, it is taboo to be a self-disclosure person. A self-disclosure person is seen as an arrogant person. This cultural value will continue to be carried by individuals. Since long time ago, the culture has been taught to accept other people without showing self-disclosure to others. Thus, over time, most Javanese people have been close people (Suseno \& Reksosusilo, 1983; Liu, 2018; Seralurin \& Yendra, 2019).

Moreover, self-disclosure, as has been explained above, is different from one another. The results of the study of Nugroho (2016), states that Madurese teenagers and Javanese adolescents are different in expressing themselves. Madura people are more open compared to Javanese people. Javanese philosophy with the attitude of a wedi, isin, and sungan is reflected in the "respect" cultural values that they have. It has been explained that cultural values influence the way people behave. The attitude of wedi, which is interpreted as fear, isin which is meant as shame, and sungan which is meant as hesitation, is related to feeling bad or feeling guilty when expressing something that is considered to hurt another person later. For Javanese, to hurt other people's feelings is a despicable attitude.

Gainau, M. B. (2019). Self-disclosure effect on cultural context of Papuan teenagers. International Journal of Social Sciences and Humanities, 3(2), 62-70. https://doi.org/10.29332/ijssh.v3n2.293 
Furthermore, Barnlund (1979), states that there were differences in the openness of easterners and westerners. Westerners are more open than easterners. He has found that Americans are more open in receiving information than Japanese people. The information mentioned is related to physical appearance, sex problems, financial work, and personal characteristics. Similar to Barnlund (1979); Chen (1995), has also found that there were differences between American students and Chinese students. Self-disclosure of American students is higher than the Chinese students. American students have higher self- disclosure in discussing opinions, interests, occupations, financial problems, personality, physical, and other topics such as parents, strengths, acquaintances, relationships, etc.

Related to the description above, self-disclosure of Papuan teenagers, especially those who are in junior high school, needs to be researched as well. It is believed that the type of phenomena is unique. Based on preresearch conducted by the research, most Papuan teenagers have got special self-disclosure to their peers. However, they are less open to their teachers or students counselors, especially in discussing their personal problems as well as their academic problems. As seen, they are more likely to be open to friends who have the same culture.

This, theoretically, is due to the strong closeness of cultural ties. However, it is more interesting since there were some teenagers students who have got high self-disclosure to other friends with different cultures, such as with Javanese friends, friends from Makasar, friends from Kupang and so on. Related to the phenomena, it is stated that culture has a great influence on self-disclosure. Counting such thoughts, the current research is viewed as important to be conducted. It is conducted to analyze the relationship between self-openness and culture.

\section{Materials and Methods}

In this section, the researcher presents materials related to some theoretical view of self- disclosure, and culture. Following the presentation, the research describes the research method of current research.

\section{Self-Disclosure}

Jourard \& Lasakow $(1958 ; 1964)$ state that self- disclosure is introduced into psychological and communication. It is the process of making the self known to others. Their message, to put it simply, was that in appropriate circumstances it was healthier to reveal feelings, and other personal matters, than to suppress them. Disclosing oneself, based on the opinion of Jourard \& Lasakow (1958; 1971), is positive and desirable. Furthermore, self-disclosure is understood as self-talk to others in order to inform thought, feeling, and desire. Jourard (1971), states that self-disclosure can be formed by 6 indicators including; 1) attitudes and opinions; 2) taste and interest; 3) work or education, 4) finance; 5) personality and 6) physical appearance. Measurement of self-disclosure by Jourard \& Lasakow (1958), is divided into 60 statement items representing 6 indicators.

Loiacono (2015), states that in self-disclosure, individuals start from the orientation stage which begins with discussing general and simple things, then enters the exploratory affection stage, namely the intensity of the topic discussed increases and begins to express an attitude towards an event.

In contrast to Jourard \& Losakow (1958); Devito et al., (2001); Taylor et al., (2001), Korry \& Suartini (2019), argue that self-disclosure is influenced by several factors, including disclosure from others, group size, topic, valence, relationships with recipients and types of sex, as well as culture. Each nation with its own cultural view style has got a unique self- disclosure.

\section{Culture}

Culture is a whole complex of knowledge, beliefs, arts, morals, laws, customs, and all other abilities and habits acquired by someone as a member of society (Horton \& Chester, 1996). In line with these statements, According to Koentjaraningrat (1994), regional culture is the same as the concept of ethnicity. Culture is inseparable from the pattern of community activities. Furthermore, cultural diversity depends on geographical factors. The greater the area, the more complex the cultural differences from one another. 
According to Garna (2008), local culture is part of a scheme from the level of hierarchical culture. In addition, local culture is complementary to regional culture. The regional culture is an essential part of the formation of national culture. Some regional culture is isolated.

There are four factors that determine the rank of isolation: (1) geographical distance, (2) lack of modern communication and technology facilities, (3) lack of social interaction with other communities, and (4) primitive minds (Hamidy, 2004). Those four factors influence cultural values. According to Sumaatmadja (2000) and Suparlan (2003), cultural values are related to the needs of knowing bad and good, wrong and right, sacred and unsacred, beautiful and bad, etc. The cultural value possessed by society is not something static but continues. It changes from one generation to the next generation. Finally, culture itself is as a thinking pattern that acts as a general guideline for community groups in the form of habits, values, language, ideas, and artifacts (Koenjtraningrat, 1985).

\section{Self-Disclosure and Cultural Relationship}

Self-disclosure is very beneficial for two people who make a relationship of intimacy, such as between friends, family, or other relatives. A close relationship will foster compassion and trust between individuals (Miyers, 2006). Calhoun \& Tedeschi (2014), state that in order to provide information, people must express their feeling and think based on honesty and openness. In other words, what conveyed to others should be true.

Self-disclosure will be useful if individuals with each other share their feelings or thoughts happily and openly. According to Devito et al., (2001), there are several benefits that will be obtained by someone if they want to reveal information about themselves to others. The benefits are: (1) other people will know better about themselves, and (2) there will be stress released when they share problems they are facing. Meanwhile, Perillo (2000), states that the benefits of one's self-disclosure are (1) people can obtain more information from various knowledge, (2) individuals will become aware of themselves, (3) people will accept others as they are, and (4) people will get greater trust from others.

Related to the benefits of self-disclosure above, Celasun (2019), explains that self-disclosure is useful since it can increase the familiarity based on trust and family. With self-disclosure, other people will obtain information about the path of their thoughts and feelings. Furthermore, each individual will know what is inside them. Another advantages of establishing relationship based on self-disclosure with others, namely (1) increasing friendship among individuals, (2) increasing acceptance of friends, (3) building better relationship by feeling comfortable being near the person, (4) opening up to strengthen affection between two people based on mutual respect (Davis, 2018).

Chelune \& Figueroa (1981), state that through self-disclosure, familiarity will increase. It helps people to know themselves, understand clearly what they want and what they are doing in their communication with others (Volz et al., 2019). Calhoun \& Tedeschi (2014), suggest three uses of self-disclosure, namely (1) opening up to strengthen affection, (2) being able to let go of feelings of guilt and anxiety, and (3) being a means of human existence that always needs a place to tell stories.

Related to the current study, the importance of self-disclosure for students, is that it will improve the social relations of students. This is in accordance with the objectives of counseling, among others: (1) improve students' ability to interact interpersonally with others, (2) improve students' ability to accept and express opinions and argue dynamically, creative and productive, (3) improving students' ability to behave and interpersonal relationships in schools and in the wider community by upholding manners, manners and values of religion, custom, law, science and habits that apply, (4) improving relationship between students and peers dynamically, harmoniously, productively, and (5) increasing understanding of school conditions and regulations and trying to implement them dynamically and responsibly.

The environment influences the formation of culture, one of which is social behavior. Thus, there is a relationship between culture and social behavior (Triandis, 1994). Culture simply means all ways of life that have been developed by members of society. With certain cultures which consist of ways of thinking, ways of acting, and ways of feeling. They are manifested in religion, law, language, art, and habits. Koenjaraningrat (1985), says there are three forms of culture, namely (1) in the form of ideas, (2) in the form of behavioral activities, and (3) in the form of objects and human works.

Gainau, M. B. (2019). Self-disclosure effect on cultural context of Papuan teenagers. International Journal of Social Sciences and Humanities, 3(2), 62-70. https://doi.org/10.29332/ijssh.v3n2.293 
A culture that influences the process of forming social behavior is subjective culture. Subjective culture deals with how individuals perceive, categorize, trust, and assess things in their environment. Likewise, selfdisclosure skills is a social behavior that influenced by culture (Brehm, 1992). The culture, such as attitudes, norms, and values in certain groups (Triandis, 1994), consists of individualistic culture and collectivistic culture.

In an individualistic culture, a person's behavior describes personal attitudes, while collectivistic culture pays more attention to group norms (Gelfand et al., 2000). In an individualistic culture, individuals perceive themselves to be autonomous and independent. Next, the individual collectivist culture is more concerned about the goals of groups (Triandis, 1994).

Michael et al., (2018), argue that there are two obstacles that exist in society. The obstacles affect selfdisclosure negatively. They are:

1) Cultural restrictions related to self-disclosure. It is a kind of closed-cultures that make it difficult for someone to express themselves to others.

2) Another aspect that inhibits self-disclosure in social life as the development of "lying" culture (Henry, 1963).

Moreover, Heraty (1986), says that emotions, motivation, and expectations influence a person's cultural perception. According to Sue \& Sue (1990), the East nations living in America, like other Asian nations, are more receptive to feelings. Their communication is one-way, namely from the old to the young. They believe that silence is gold. They live in an extended family. They are different from the people in western countries who tend to be more open. In the results of Kurt Lewin's research (Raven \& Rubin, 1983), it is revealed that Americans seemed to be more open than Germans, while the results of Morgan's study reveal that white students were more open than black students in America (Morgan, 2013).

Furthermore, Ludwig et al., (1986), state that Americans are more open than Mexico. Likewise, in Chinese culture, children may prefer not to open/reveal personal information to their parents but they still have close attachments to their families. Barnlund \& Yoshioka (1990), reveal that the American and Japanese countries did different self-disclosures. Self-disclosure of Japanese people is more closed, while Americans are more open about everything.

According to Cunningham (1981), states that women are more often open to fear, lack of strength. Women are more express while men are more restrained. Another opinion is that men are more self-proclaimed, achievement-oriented, and more dominant, while women are more responsive socially, passive and relentless. The present reality, especially for men, recognizes the existence of the same role or gender. With the understanding of gender roles, it will improve the atmosphere of intimacy between men and women.

A person's openness can be seen as one type of direct communication. Won-Doornink (1985), compared self-disclosures in the USA and Korea and found that they were expected to be higher in the USA. From these findings, it can be concluded that this difference is a typical difference between eastern culture (collectivistic) and western culture (individualistic).

Research conducted by Barnlund \& Yoshioka (1990), on Japanese and American people found that Japanese men were more open to male friends, while Japanese women disclose more with fellow women. Americans, both men, and women communicate more with friends than parents. Related to the phenomena of the current research, the previous studies indicate that the topics in disclosure and gender chose to have several different trends by men and women, as well as between different cultures. In contrast to Barnlund \& Yoshioka (1990); Kellam et al., (2018), state that there is a relationship between self-disclosure and age as well as gender. Generally, male sex is more influenced by mental attitudes that are difficult to open. Shane et al., (2018), explain that current self-disclosure in adolescents is more exposed to public media. It is generally performed in social media such as Facebook, Instagram, etc.

\section{Method}

This study applied a quantitative method. It used the statistical test as the research instrument. It was conducted through validity and reliability tests. Next, factor analysis of each variable was applied for testing the instrument feasibility. For the correlation coefficient and hypothesis examination, the statistical T-test was used in order to examine the magnitude of influence. The population in this study were all 919 students of Public Middle School in Sentani- Papua, Indonesia. The random sampling technique was used to get the 
sample. Vockel (1983), states that $5-20 \%$ of the population should be taken to have a sample. Based on this opinion, the number of respondents that were taken as the sample is 183 students. Finally, to measure selfdisclosure, the current research used a type of measurements developed by Jourad (1958). It was 78 item statements. To measure cultural variables, the current research used a type of measurements developed by Koenjaraningrat (1979).

\section{Results and Discussions}

Based on the results of self- disclosure validity, only 64 items meet the requirement while 14 items do not meet the requirement. For the culture validity, only 68 items meet the requirements and 17 items do not meet the requirements. Next, based on the results of the instrument reliability test results, it is obtained that the self- disclosure reliability coefficient is 0.823 , while the culture reliability coefficient is 0.810 . Finally, the results of factor analysis show that from the variable of self-disclosure, that consists of 64 items, 60 items meet the requirements, while 4 others do not meet the requirements. From the culture variables that consists of 68 items, 63 items meet the requirement while 5 items do not meet the requirement.

It is also found that $56.28 \%$ of Papuan teenagers have got self-disclosure, while $43.71 \%$ of them have got low self-disclosure. Also, there are no teenagers with high self-disclosure in Papua. Those who have selfdisclosure is caused by the inability of expressing themselves. From the examination of cultural analysis, it was found that $62.29 \%$ of teenagers have got understanding of media culture, while $37.70 \%$ of them have got a low understanding of media culture. In addition, the results of the regression analysis show that there is a significant correlation between self-disclosure. This finding shows that self-disclosure is very influential in the culture of Papuan teenagers, especially for teenagers who live in Sentani.

\section{Conclusion}

Based on the results and discussion, it is concluded that self-disclosure of Papuan teenagers has a strong and significant effect on culture. It can be shown from the discussion that the valid data were 64, while the liability of the data was 8.23. By fulfilling the Standard Measure of Sampling Adequacy (MSA), 0.5> is considered as valid. The same statement is addressed to the cultural understanding of teenagers. The statistical result, also, has shown that the cultural understanding of the teenagers has fulfilled the Standard Measure of Sampling Adequacy (MSA), namely 0.5>.

Furthermore, it is found that both variables, namely self-disclosure and cultural understanding are low. This means that teenagers could not express their feeling because their understanding of the culture is low. That is why it is concluded that self-disclosure of Papuan teenagers has got a strong and significant effect on culture. The local culture of Papuan Teenagers, which is not disclosed with the general world's view has to lead them to be closed-minded teenagers who cannot express themselves well.

\section{Acknowledgments}

The author would like to thank the editor of IJSSH for their valuable time, support and advice in completing the current study. 


\section{References}

Agra, I. B., Gelgel, I. P., \& Dharmika, I. B. (2018). Pressure on socio-cultural towards post-divorce Hindu women in Denpasar city. International Journal of Social Sciences and Humanities, 2(3), 63-78. https://doi.org/10.29332/ijssh.v2n3.191

Ardhana, I. K., \& Wijaya, I. N. (2017). Indian influences on Balinese culture: the role of Hinduism and Buddhism in present day Bali. International Research Journal of Management, IT and Social Sciences, 4(1), 88-105.

Barnlund, D. C. (1979). Public and private self in Japan and the United States. 日本人の表現行動.

Barnlund, D. C., \& Yoshioka, M. (1990). Apologies: Japanese and American styles. International Journal of Intercultural Relations, 14(2), 193-206. https://doi.org/10.1016/0147-1767(90)90005-H

Brehm, S. S. (1992). Intimate relationships. Mcgraw-Hill Book Company.

Buhrmester, D. (1998). Need fulfillment, interpersonal competence, and the developmental contexts of early adolescent friendship.

Calhoun, J. F., \& Acocella, J. R. (1990). Psikologi tentang penyesuaian dan hubungan kemanusiaan (edisi ketiga). Satmoko, RS (Penerjemah) New York: McGraw-Hill.

Calhoun, L. G., \& Tedeschi, R. G. (2014). The foundations of posttraumatic growth: An expanded framework. In Handbook of posttraumatic growth (pp. 17-37). Routledge.

Celasun, D. (2019). Adolescents' self-disclosure to mother: links to attachment anxiety, avoidance and perceived parenting style of the mother (Doctoral dissertation, İstanbul Bilgi Üniversitesi).

Chelune, G. J., \& Figueroa, J. L. (1981). Self-disclosure flexibility, neuroticism, and effective interpersonal communication. Western Journal of Speech Communication, 45(1), 27-37. https://doi.org/10.1080/10570318109374026

Chen, G. M. (1995). Differences in self-disclosure patterns among Americans versus Chinese: A comparative study. Journal of Cross-Cultural Psychology, 26(1), 84-91. https://doi.org/10.1177\%2F0022022195261006

Corey, G. (2015). Theory and practice of counseling and psychotherapy. Nelson Education.

Cunningham, J. D. (1981). Self-disclosure intimacy: Sex, sex-of-target, cross-national, and" generational" differences. Personality and Social Psychology Bulletin, 7(2), 314-319. https://doi.org/10.1177/014616728172021

Davis, M. H. (2018). Empathy: A social psychological approach. Routledge.

Devito, J. A., Clark, D., \& Shimoni, R. (2001). Messages: Building interpersonal communication skills. Addison Wesley Longman.

Gainau, M. B. (2009). Pengembangan inventori self disclosure bagi siswa usia sekolah menengah atas. Jurnal Ilmu Pendidikan Universitas Negeri Malang, 15(3).

Garna, Y. K. (2008). Budaya Sunda: melintasi waktu menantang masa depan. Lembaga Penelitian Unpad dan Judistira Garna Foundation.

Gelfand, M. J., Spurlock, D., Sniezek, J. A., \& Shao, L. (2000). Culture and social prediction: The role of information in enhancing confidence in social predictions in the United States and China. Journal of CrossCultural Psychology, 31(4), 498-516. https://doi.org/10.1177/0022022100031004004

Hamidy, U. U. (2004). Jagad Melayu dalam lintasan budaya di Riau. Bilik Kreatif Press.

Henry, J. P. (1963). Circulatory basis of fluid volume control. Physiological Reviews, 43(3), 423-481.

Heraty, J. M., \& Barber, K. N. (1990). Biology of Obeza floridana (Ashmead) and Pseudochalcura gibbosa (Provancher)(Hymenoptera: Eucharitidae). Proceedings of the Entomological Society of Washington, 92(2), 248-258.

Heraty, T. (2009). Jauh dan Dekat Antar Manusia. Manusia: teka-teki yang mencari solusi: hommage untuk Prof. Dr. M. Sastrapratedja, 141.

Horton, P. B., \& Hunt, C. L. (1996). Sosiologi (terjemahan Aminudi Ram dan Tita Sobari). Jakarta: Erlangga. Jourard, S. M. (1958). Personality adjustment: An approach through the study of healthy personality. Macmillan. Jourard, S. M. (1971). Self-disclosure. An Experimental Analysis of the Transparent Self.

Jourard, S. M., \& Jourard, S. M. (1971). The transparent self(pp. 133-152). New York: Van Nostrand Reinhold.

Jourard, S. M., \& Lasakow, P. (1958). Some factors in self-disclosure. The Journal of Abnormal and Social Psychology, 56(1), 91.

Jourard, S. M., \& Richman, P. (1963). Factors in the self-disclosure inputs of college students. Merrill-Palmer Quarterly of Behavior and Development, 9(2), 141-148. 
Kellam, J. F., Meinberg, E. G., Agel, J., Karam, M. D., \& Roberts, C. S. (2018). Introduction: fracture and dislocation classification compendium-2018international comprehensive classification of fractures and dislocations committee. Journal of orthopaedic trauma, 32, S1-S10.

Kellam, S. G., Brown, C. H., Rubin, B. R., Ensminger, M. E., Guze, S. B., Earls, F. J., \& Barrett, J. E. (1983). Childhood psychopathology and development.

Kellam, S. G., Brown, C. H., Rubin, B. R., Ensminger, M. E., Guze, S. B., Earls, F. J., \& Barrett, J. E. (1983). Childhood psychopathology and development.

Koentjaraningrat, K. (1985). Mentalitas dan Pembangunan. Jakarta: Gramedia.

Koentjaraningrat, R. M. (1979). Javanese magic, sorcery and numerology. Masyarakat Indonesia, 6(1), 37-52.

Koentjaraningrat. (1994). Irian Jaya: membangun masyarakat majemuk (Vol. 5). Djambatan.

Korry, P. D. P., \& Suartini, N. W. (2019). Hedonism and culture toward impact of shopping behavior. International Journal of Social Sciences and Humanities,3(1), 125-133. https://doi.org/10.29332/ijssh.v3n1.260

Larasati, B. (1992). Komunikasi Efektif. Makalah disampaikan dalam Pelatihan Public Relation yang dilaksanakan Lembaga Pendidikan Abisheka Yogyakarta.

Liu, X. (2018). International communication of intangible cultural heritage in central plains: a case study of Chinese Wushu. International Journal of Social Sciences and Humanities,2(3), 196-204. https://doi.org/10.29332/ijssh.v2n3.238

Loiacono, E. T. (2015). Self-disclosure behavior on social networking web sites. International Journal of Electronic Commerce, 19(2), 66-94.

Ludwig, D., Franco, J. N., \& Malloy, T. E. (1986). Effects of reciprocity and self-monitoring on self-disclosure with a new acquaintance. Journal of Personality and Social Psychology,50(6), 1077. http://dx.doi.org/10.1037/0022-3514.50.6.1077

Lumsden, A., \& Krumlauf, R. (1996). Patterning the vertebrate neuraxis. Science, 274(5290), 1109-1115. https://doi.org/10.1126/science.274.5290.1109

Michael, R. D., Webster, C. A., Egan, C. A., Stewart, G., Nilges, L., Brian, A., ... \& Vazou, S. (2018). Viability of university service learning to support movement integration in elementary classrooms: Perspectives of teachers, university students, and course instructors. Teaching and Teacher Education, 72, 122-132.

Morgan, A. L. (2013). Cultural orientation and privacy management: an examination of intra-ethnic same-sex friendships (Doctoral dissertation, San Diego State University). http://hdl.handle.net/10211.10/4793

Myers, D. (2006). Surfactant science and technology. John Wiley \& Sons.

Nugroho, M. A. (2016). Urgensi dan Signifikansi Pendidikan Islam Multikultural Terhadap Kompleksitas Keberagamaan di Indonesia. ATTARBIYAH: Journal of Islamic Culture and Education, 1(2), 179-210.

Perillo, J. M. (2000). The origins of the objective theory of contract formation and interpretation. Fordham $L$. Rev., 69, 427.

Seralurin, Y. C., \& Yendra, -. (2019). The intensity of stock selection: A case of young Papuan investors. International Journal of Social Sciences and Humanities, 3(1), 171-178. https://doi.org/10.29332/ijssh.v3n1.262

Shane-Simpson, C., Manago, A., Gaggi, N., \& Gillespie-Lynch, K. (2018). Why do college students prefer Facebook, Twitter, or Instagram? Site affordances, tensions between privacy and self-expression, and implications for social capital. Computers in Human Behavior, 86, 276-288.

Sue \& Sue $(1990$

Sue, D. W. (1990). Culture-specific strategies in counseling: A conceptual framework. Professional Psychology: Research and Practice, 21(6), 424.

Sumaatmadja, N. (2000). Manusia dalam konteks sosial budaya dan lingkungan hidup. Bandung. Alfabeta.

Suparlan, P. (2003). Bhinneka Tunggal Ika: Keanekaragaman Sukubangsa atau Kebudayaan. Jurnal Antropologi Indonesia. 72(1), hlm. 29.

Suseno, F. M., \& Reksosusilo, S. (1983). Etika Jawa dalam Tantangan. Yogyakarta: Penerbit Yayasan Kanisius.

Taylor, H. F. (1997). Cement chemistry. Thomas Telford.

Taylor, P. J., Catalano, G., \& Walker, D. R. (2002). Measurement of the world city network. Urban Studies, 39(13), 2367-2376.

Triandis, H. C. (1994). Culture and social behavior.

Vockell, E. L. (1983). Educational research. MacMillan Publishing Company.

Gainau, M. B. (2019). Self-disclosure effect on cultural context of Papuan teenagers. International Journal of Social Sciences and Humanities, 3(2), 62-70. https://doi.org/10.29332/ijssh.v3n2.293 
Volz, B., Valverde, K. D., \& Robbins, S. J. (2019). Effects of Genetic Counselor Self-Disclosure: an Experimental Analog Study. Journal of genetic counseling, 28(1), 18-26. https://doi.org/10.1007/s10897-018-0283-z

Won-Doornink, M. J. (1985). Self-disclosure and reciprocity in conversation: A cross-national study. Social Psychology Quarterly, 97-107.

\section{Biography of Author}

Maryam B. Gainau is a senior lecturer at Sekolah Tinggi Agama Kristen Negeri
(STAKN) Papua. Besides that, she is an active researcher who has published her
researches in many national journals as well as international journals. She,
currently, is interested in counseling. Her researches are mostly related to self-
disclosure.
Email:m.gainau@yahoo.com

